\title{
Online Web-Based Learning and Assessment Tool in Vocational High School for Physics
}

\author{
Gita Ayu Permatasari ${ }^{1, a)}$, Ellianawati ${ }^{2, b)}$, Wahyu Hardyanto ${ }^{2}$ \\ ${ }^{1}$ Program Studi Magister Pendidikan Fisika, Pascasarjana, Universitas Negeri Semarang, Indonesia \\ ${ }^{2}$ Jurusan Fisika, Fakultas MIPA, Universitas Negeri Semarang, Indonesia \\ $\bowtie:{ }^{a)}$ gitaayupermatasari@students.unnes.ac.id, b)ellianawati@mail.unnes.ac.id
}

\begin{abstract}
ICT has transformed the conventional into a modern learning system, demanding innovation in the delivery. This study aims to develop, knowing the feasibility of online web-based learning and assessment tool in physics, as well as knowing students' learning results in the ICT media. This study research \& development (R\&D) method using Borg \& Gall model. Which refers to the potential problem through data collection, product design, validation, revision of the product, product testing, revision of usage. The feasibility testing of media and material was carried out by two material expert validators and two media expert validators with a small group trial conducted on students consisting of 13 respondents and large group trial conducted on students consisting of 40 respondents. We use online media for web-based learning and assessment tool in vocational high school for Physics subject, and the results of the study show that this application generates individual assignments, marks student responses, supplies students with the rapid feedback, and records student activities. The student activity log provides insight into student learning habits. Its a reference for assessment. This application meets the requirements as a learning media. The results of the validation by an expert material on online web-based learning and assessment tool gets a percentage of an average score of $82 \%$, and the material gets a percentage of $81.33 \%$ criteria very feasible.
\end{abstract}

Keywords: web-based assessment, computer-assisted learning, physics learning, student feedback

\section{INTRODUCTION}

The implementation of the 2013 curriculum emphasizes information and communication technology (ICT) in learning. The use of Literacy in Information and Communication Technology (ICT) or ICT Literacy and the internet as a learning media in the field of education are increasing (Fauzi 2016). Information technology is crucial because it is needed for the development of our education system (Habibi et al. 2014), in the future, all education subjects included ICT at all levels (Quijada 2015). The use of computers today is part of everyday life because large computers can be used to study physics concepts (Drigas et al. 2016). Many secondary school teachers have used ICT in learning physics, such as using Macromedia Flash, video, Microsoft Word, and Excel Spreadsheets. However, the teacher has not included the ICT media to student literacy. Therefore it is essential for teachers to improve their ability to use ICT and learning in learning.

The results of observations during a teaching in our vocational high schools have several problems including the availability of diverse learning resources around students but cannot be managed and utilized optimally in learning; teachers are still the only primary learning resource. If 
the teacher is not present in the classroom, then other learning resources, including books, cannot be utilized by students, so the teacher needs to be there. Students lack the initiative to look for practice questions and other learning resources and find themselves solving problems. Another problem raised by the principal was the existence of industrial work practices carried out for six months in two semesters even though there was much material to be conveyed, time limitations most of the tasks were given to students usually without feedback. The distribution of student exam results are still using manual transfer file and processing offline using Microsoft Excel by the teacher from each subject, and then all teachers will combine all excel files, so this method will take a longer time to process the final exam results than using online web learning and assessment tools. Using the online, the teacher only needs to log in and put that exam results in the online database, and then the system will do the rest about the assessment tools.

The rapid development of technology and the internet has created a variety of new learning media that are considered more supportive of the learning process, one of which is web technology is one way we interact and learn through the internet using a variety of internet-connected devices. Implementation of ICT in the learning process and learning outcomes for understanding material physics (Drigas 2016). The author develops an application to create an online web-based learning and assessment tool in physics. The online assessment material can be used to support the learning process that contains subject matter and questions. The questions can be accessed through crossplatform and accessed anywhere as long as internet access is available. E-learning material increases student interest and increases their motivation to study physics and science (Jarosievitz 2012). Online media are classified into media that can be accessed through browsing media on computers, notebooks, smartphones, and tablets. Online web-based learning and assessment in physical tools facilitate students to carry out the learning process independently and help teachers interact not only in face-to-face classes. The results of the research from Jakarta Physics Teachers also welcomed web-based media (Kalatting 2015). Web media with video is a resource that can be used to study physics (Brekke 2010). The results of implementation and testing show that this learning application is able to provide interesting visualization with interactive multimedia support. Alternative media like this are also more practical and interesting, so they motivate children to use and learn (Prasetya 2010).

Online web learning resources have valuable addition for students to get better test results in each student with their different learning styles (Bawaneh 2011). Online web learning can be a partner or complementary with conventional learning in the classroom. Online web learning is even a great complement to classroom learning models or as a powerful tool for enrichment programs (Husamah 2012). We need an online web learning platform that can be the right tools for students in order to get better results in their learning process and help the teacher to evaluate the learning results of students. Barger dan Byrd (2011) also need the assessment tool that generates individual assignments marks student responses, supplies students with the rapid feedback, and records student activities. This study aims to develop an online web-based learning and assessment tool in physics for business and energy material. Knowing the feasibility of online web-based learning and assessment tools in physics, and knowing the results of the assessment of students in using online web-based learning and assessment tools in physics.

\section{RESEARCH METHODOLOGY}

This study using Borg \& Gall model covering potential and problem stages, data collection, product design, design validation, product design revision, product testing, product revision, usage testing, product revisions, and mass production. The feasibility testing of media and material was carried out by two material expert validators and two media expert validators with small group trials conducted on students consisting of 13 students. Field trials were conducted on Vocational High School B students consisting of 40 students. The sampling technique is purposive sampling. The data collection technique of this study is by observation, interviews, validation instruments, and student response questionnaires. Data analysis was carried out descriptively and quantitatively. Expert validation questionnaire The value of each item is the percentage of the average value of the 
assessment of the validator. The average formula used calculates aspects, Average value $=$ the total number of answers from expert validators/number of validators.

\section{RESULTS AND DISCUSSION}

There are many online web learning platforms are free accessed like Moodle, Schoology, and Edmodo. These platforms have advantages and disadvantages. They are not designed exclusively for the school environment is one of their disadvantages, because that platform is for general user purpose. We need to use online web learning and assessment tools platform that has full support with the school environment, for example, the platform must have school entity in their databases like the classroom, teachers, students, subjects, students' progress, and final exam results. The platform that has these features in the school environment will optimize the online web learning and assessment tools used. We are developing the online web learning platform that designed for the school environment in media. Online with those features that still not available in another platform.

Development of the Online Web-Based Learning media and tool assessment can be seen in FIGURE 1. The explanation is as follows. The initial step of development is identifying problems by gathering information relevant to the development of Online Web-Based Learning and Assessment tools. Potential problems and data collection are carried out by looking at the school directly for conducting interviews and giving questionnaires. Data obtained by students have obtained internet facilities, has ICT literacy and requires web-based learning media to direct their ICT literacy.

Product design by developing and designing products that are the result of developing an LTE web admin display that is open source. Product design validation by material experts and media. Material experts by physics teachers from Vocational High School A, Expert Media by multimedia productive teachers at Vocational High School B and productive teachers Software Engineering at Vocational High School A. Validation is done to provide product feasibility when tested. The results of media experts obtained recommendations for the feasibility of graphics, the suggestion that the image display formula needs to be enlarged, media attractiveness, Web-Based Learning, and UserUse Assessments require an internet connection, the feasibility of the language suggested by the formula can be written with a more precise font. Media experts also suggest having plans to anticipate if the internet network field trials in schools do not support. After revising the initial product, the expert stated that it was feasible to be tested in the field, so the study tested small scale products with respondents 13 students. The results of the validation by the material experts, obtained suggestions for content feasibility, namely clarifying the image on the material provided, using the formula following the manual on the appropriate material. The notions by existing material concepts suggest the presentation of material experts regarding the accuracy of the material are complementary KD, indicators, and learning objectives, clarifying the appearance of structured material (TABLE 3).

The purpose of a small scale trial is to get information that is used as product improvement. The input obtained is that the web needs to be made more practice questions. After being approved by media and material experts, the product was tested on a large scale with the number of respondents 40 students of the Vocational High School A. These respondents selected by purposive sampling to measure and validate in order to provide information about student assessment results with online media Web-Based and Assessment Tool in Physic. Analysis of results of field trials. At this stage, an analysis of the Online Web-Based and Assessment Tool in Physics is used. Revision of Web products.

Furthermore, improvements are made to web products as the main learning media. This improvement effort is carried out with guidelines for the results of field trial analysis that has been evaluated by media experts and material experts. The final web media learning product. This is the final Web-Based and Assessment Tool in Physic product that is socialized to the field in class X of Vocational High School B.

Analysis of expert test results was obtained by criteria in TABLE 1 . The results of the analysis of the material expert feasibility criteria can be seen in TABLE 3.

the material expert feasibility criteria can be seen in TABLE 3. 
TABLE 1. Percentage of product eligibility criteria. Source: from Kusyeni's research, Mery (2017: 67-69).

\begin{tabular}{ll}
\hline Score Percentage Interval & Criteria \\
\hline $81 \%-100 \%$ & very decent \\
$61 \%-80 \%$ & Worthy \\
$41 \%-60 \%$ & Quite decent \\
$21 \%-40 \%$ & Less feasible \\
$<20 \%$ & Very Unworthy \\
\hline
\end{tabular}

TABLE 2 Validation of Design by Material Experts

\begin{tabular}{ll}
\hline Draft 1 (Initial Product) & Draft 2 (Revision) \\
\hline There are no KD and Learning Objectives & $\begin{array}{l}\text { Placing KDs and Learning Objectives in Each } \\
\text { Material }\end{array}$ \\
$\begin{array}{l}\text { Not yet given a written explanation and } \\
\text { description of each formula }\end{array}$ & $\begin{array}{l}\text { Clarify the writing and description of each } \\
\text { formula }\end{array}$ \\
\hline
\end{tabular}

The results of the analysis from collected questionnaire data are shown in TABLE 3. The following:

TABLE 3. Percentage of product eligibility criteria

\begin{tabular}{lllll}
\hline Aspect & $\begin{array}{l}\text { Number of } \\
\text { material } \\
\text { expert scores }\end{array}$ & $\begin{array}{l}\text { The ideal } \\
\text { number of } \\
\text { scores }\end{array}$ & Percentage & $\begin{array}{l}\text { Eligibility } \\
\text { Criteria }\end{array}$ \\
\hline Eligibility & 41 & 50 & $82 \%$ & very decent \\
$\begin{array}{l}\text { material } \\
\text { accuracy }\end{array}$ & 40 & 50 & $80 \%$ & worthy \\
$\begin{array}{l}\text { Increased } \\
\text { curiosity } \\
\text { Total number }\end{array}$ & 41 & 50 & $82 \%$ & very decent \\
\hline
\end{tabular}

According to the material expert's suggestion, the percentage of material expert feasibility was obtained the results of the eligibility content of $82 \%$ were very feasible, the accuracy of the material was $80 \%$ feasible, increasing curiosity $82 \%$ was very feasible.

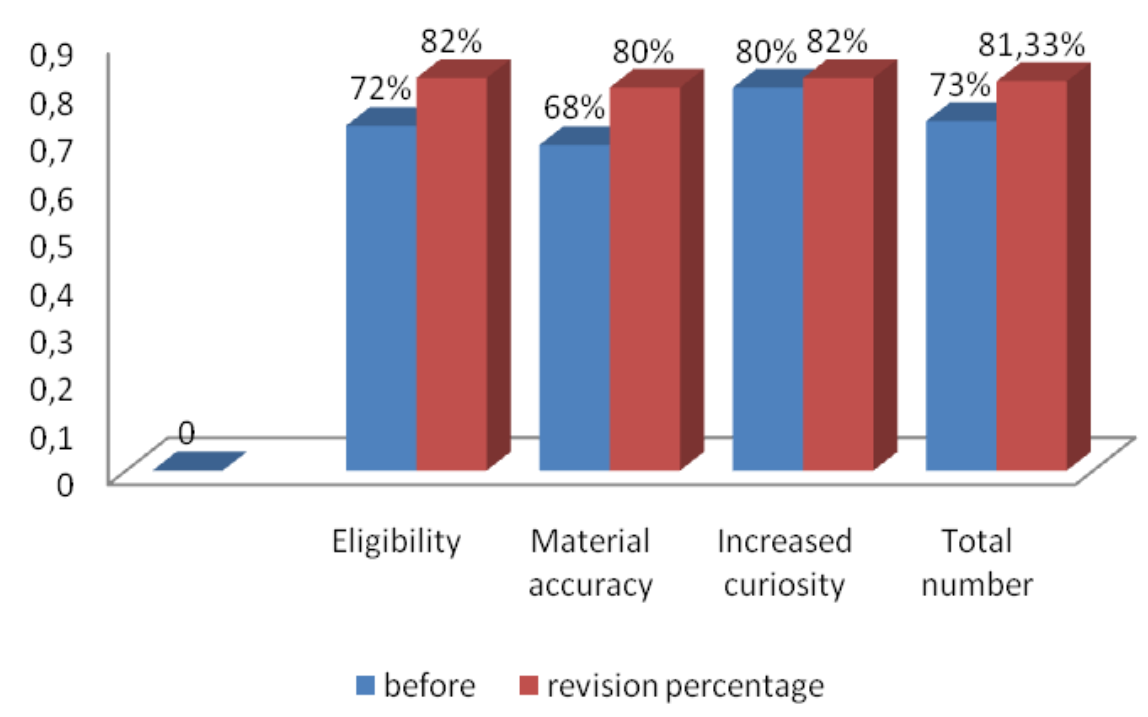

FIGURE 1. Percentage of product eligibility criteria. 
The results of the analysis from the collected questionnaire data are shown in TABLE 4 . The following:

TABLE 4. Recapitulation of media expert validation.

\begin{tabular}{lllll}
\hline Validator & Aspect & Score & Percentage & Criteria \\
\hline Design Expert & graphic eligibility & 38 & $78 \%$ & worthy \\
& Media attractiveness & 41 & $82 \%$ & Very decent \\
& Language feasibility & 41 & $82 \%$ & Very decent \\
\hline
\end{tabular}

Feasibility of graphics, the suggestion of the image display formula needs to be enlarged again, the attractiveness of the media, web-based learning users need an internet connection, the feasibility of language suggestions submitted by the formula can be written with a more precise font.

The results of field test analysis using a Likert scale with criteria $5=$ Very High (ST), $4=$ High $(\mathrm{T}), 3$ = Fairly High $(\mathrm{CT}), 2$ = Low $(\mathrm{R}), 1$ = Very Low (SR) conducted with respondents 120 students produce $82.3 \%$ (Very Interesting). The source appears in TABLE 5.

TABLE 5. Field Test of Student Response with Percentage of Interest Response

\begin{tabular}{|c|c|c|c|c|c|}
\hline Validator & Aspect & Score & $\begin{array}{l}\text { Maximum } \\
\text { Score }\end{array}$ & Percentage & Criteria \\
\hline \multirow[t]{7}{*}{ Students } & Layout & 480 & 600 & $80 \%$ & \multirow{7}{*}{$\begin{array}{l}\text { Interesting } \\
\text { very } \\
\text { interesting } \\
\text { very } \\
\text { interesting } \\
\text { very } \\
\text { interesting } \\
\text { very } \\
\text { interesting } \\
\text { very } \\
\text { interesting } \\
\text { very } \\
\text { interesting }\end{array}$} \\
\hline & User Interface & 498 & 600 & $83 \%$ & \\
\hline & Content \& language & 498 & 600 & $83 \%$ & \\
\hline & $\begin{array}{l}\text { Animation, Images \& Audio } \\
\text { from Content }\end{array}$ & 492 & $\begin{array}{l}600 \\
600\end{array}$ & $82 \%$ & \\
\hline & User Experience & 486 & & $81 \%$ & \\
\hline & Right Content & 510 & 600 & $85 \%$ & \\
\hline & Total & 2964 & 3600 & $82,3 \%$ & \\
\hline
\end{tabular}

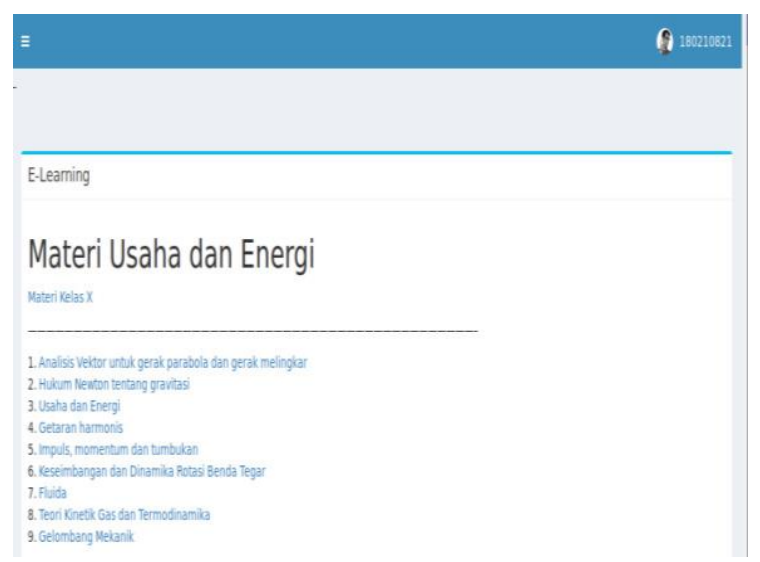

(a)

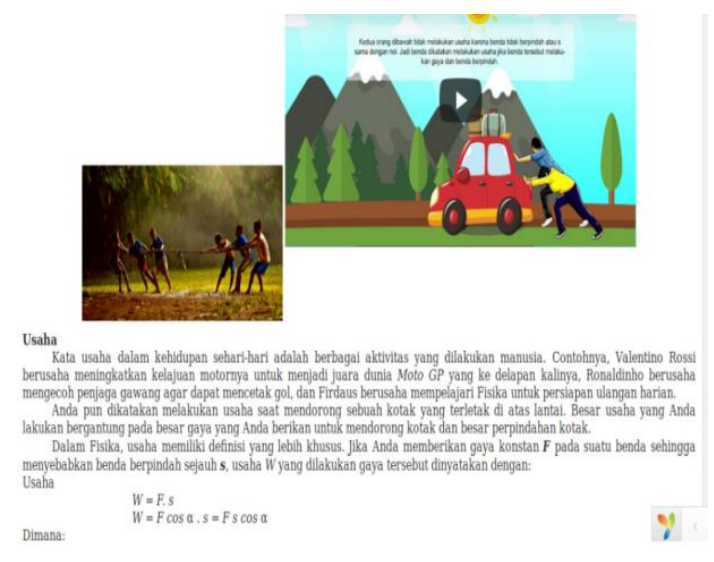

(b)

FIGURE 2. (a) Content page (b) Detailed material page, video by youtube channel uploaded by Laelana Syalala in 2016. 


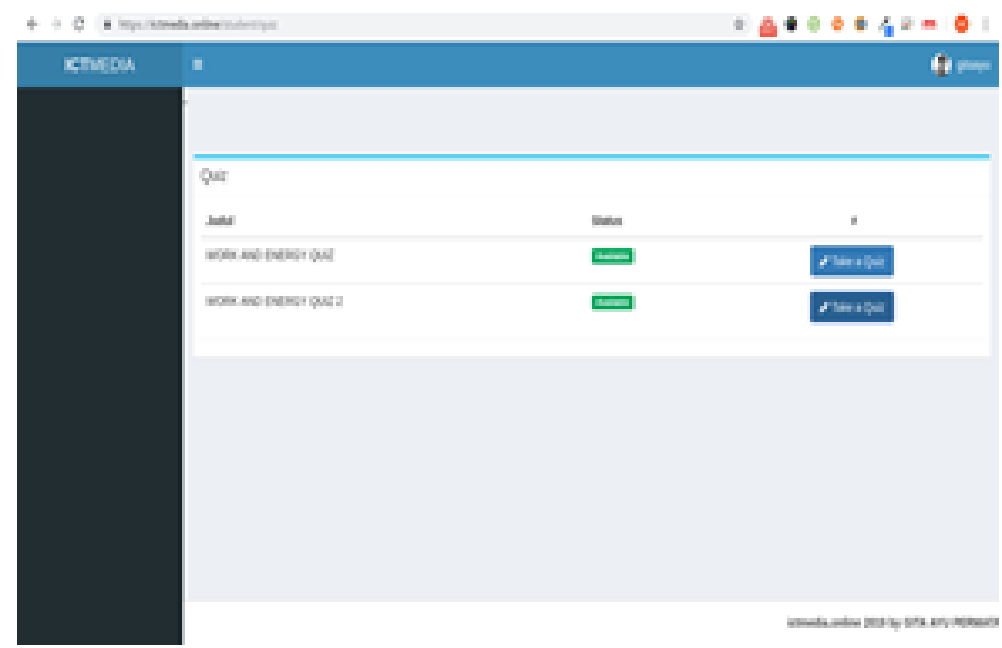

(a)

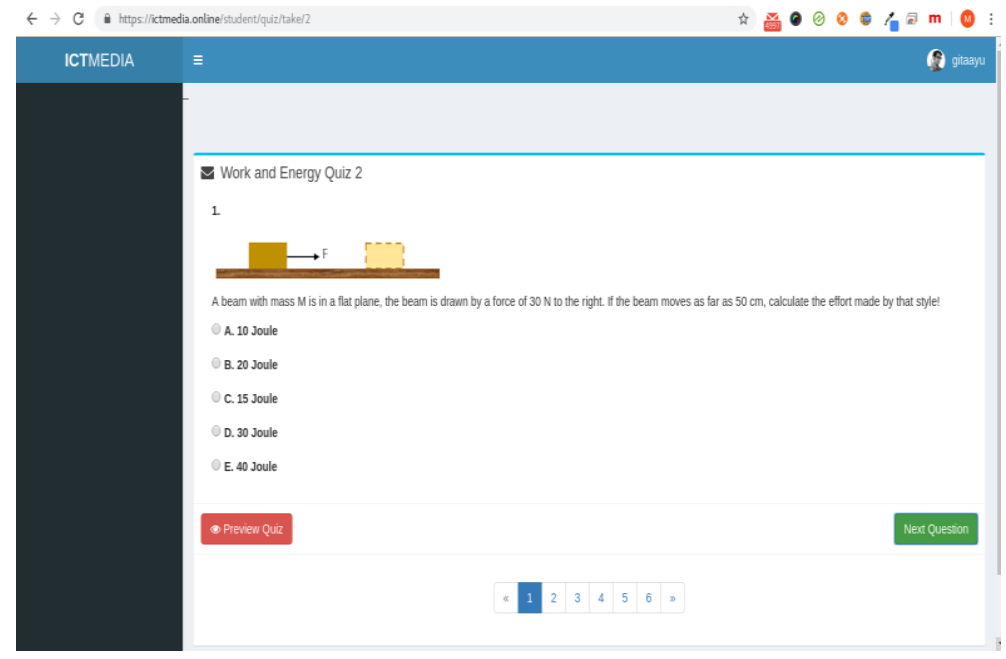

(b)

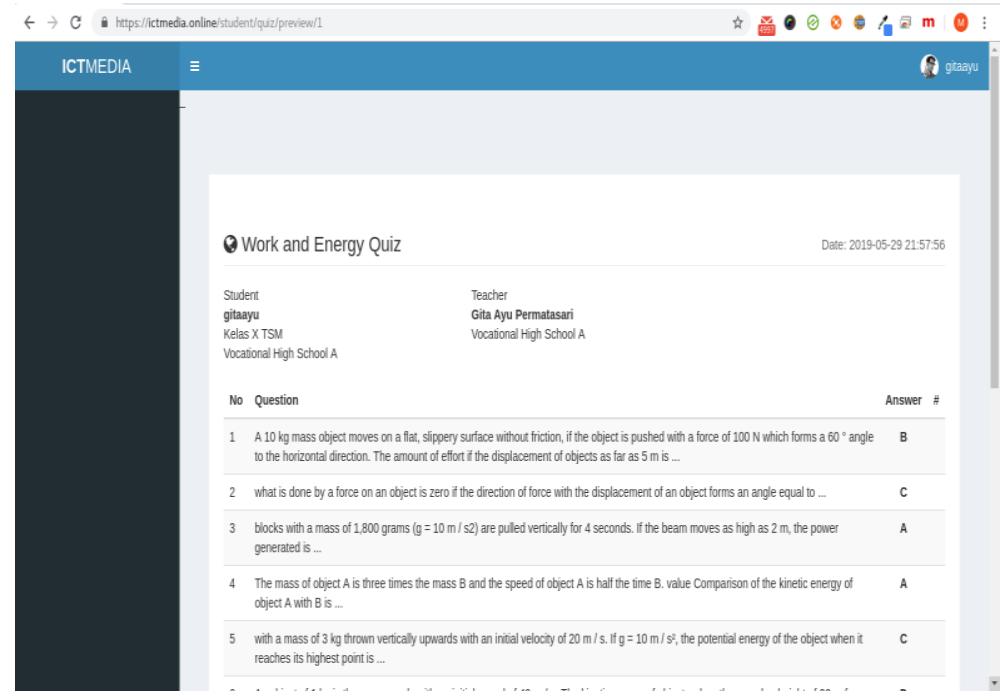

(c)

FIGURE 3. (a) Question page to be worked on (b) Multiple Choice Questions Worksheet Page (c) Page of Basic Question and Competence Review 


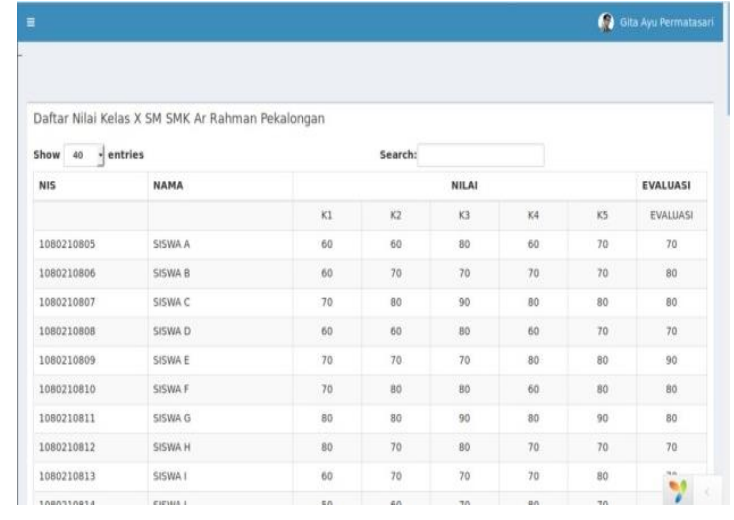

(a)

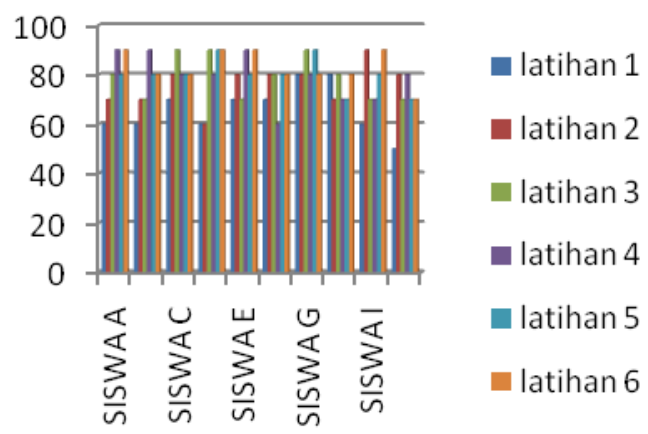

(b)

FIGURE 4. (a) student assessment page (b) graph page of student competency results using online based and in physic tool assessment conclusion

\section{CONCLUSIONS}

In this study shows that the results of the validation by material experts regarding online webbased learning and assessment tools get a percentage of average scores of $82 \%$ and material experts get a percentage of $81.33 \%$ with very feasible criteria. Online Web-based Media Learning is intended for assessment tools and learning. This application generates individual assignments, marks student responses, facilitates students with quick feedback, and records student activities. Student activity history provides an overview of student learning habits and can be used as a reference for assessment.

\section{ACKNOWLEDGMENTS}

The Authors acknowledge the principal and students from vocational high school A and B who have been willing and cooperating in this research.

\section{REFERENCES}

Barger, A \& Byrd, K 2011, 'Motivation and Computer-Based Instructional Design,' Journal of CrossDisciplinary Perspectives in Education, vol. 4, no.1, pp. 1-9.

Bawaneh, SS 2011, 'The Effects of Blended Learning Approach on Students' Performance: Evidence from a Computerized ccounting Course,' International Journal of Humanities and Social Science, vol. 1 , no. 6, pp. 63-69.

Brekke, M \& Hogstad, PH 2010, 'Potret New Teaching Method-Using Computer Technology in Physics, Matematics, and Computer Sains,' iJEP, vol. 6, pp. 53-59.

Drigas AS \& Theofania M 2016, 'ICTs Based Physics Learning,' Institute of Information and Telecommunications, vol. 6, Issue 3, pp. 53-59.

Fauzi, A 2016, 'Potret Penggunaan Tik oleh Guru Sekolah Menengah Atas (SMA) Untuk Menanamkan Keahlian Literasi Siswa Dalam Mendukung Pembelajaran Fisika,' Jurnal Profesi Pendidik, 'vol. 3, no. 2, pp. 107-113.

Habibi, Z \& Habibi, A 2014, 'The Effect of Information Technology in Teaching Physics Courses,' The Eurasia Procedings of Educational \& Social Sciences (EPESS), vol. 1, pp. 391-396. 
Husamah 2012, 'Pengembangan E - Learning Ekologi Tumbuhan Untuk Meningkatkan Kualitas Pembelajaran Dan Kompetensi Peserta Didik,' Laporan hibah pengajaran - Bermutu, Prodi Pendidikan Biologi FKIP UMM, Malang.

Jarosievitz, B 2012, 'ICT in physics teaching for secondary schools and colleges,' New Perspectives in science education

Kalatting, S, Serevina, V, \& Astra, IM 2015, 'Pengembangan Media Pembelajaran Fisika Berbasis Web Menggunakan Pendekatan Guided Discovery Learning,' Jurnal Penelitian \& Pengembangan Pendidikan Fisika, vol. 1, no. 1, pp. 1-8.

Kusyeni, Mery, 2017, 'Pengembangan Media Pembelajaran Blended Learning Berbasis Edmodo di Sekolah Menengah Kejuruan Kelas XI pada Materi Gelombang', Skripsi, pp. 67-69.

Prasetya, DD, Rahmawati, Y, \& Widiyaningtyas, T 2010, 'Konferensi Nasional dan Workshop APPI', vol. 1, no. 1, pp. 1-8.

Quijada, R 2015, 'Information and Communication Technology (ICT) in Physical Education a Theorical Review', Scientific Technical Journal, vol. 1, pp. 75-86. 